\title{
Afrophobia, moral and political disguises: Sepa lebolo ke la moeti ${ }^{I}$ MLJ KOENANE ${ }^{2}$ AND KJMAPHUNYE
}

\begin{abstract}
Violent or other attacks on nationals from other African states are a reality we have come to expect time-after-time in post-apartheid South Africa. We are once confronted with the ugly reality of barbaric and cruel acts of attacks on foreign internationals from other African states, which some have labelled "xenophobia" or "xenophobic attacks" while others term this "Afrophobia" (Black-on-Black conflict and violence directed at other Africans). We argue that this unsolicited characteristic of being African (indigenous) will never disappear unless the moral and political disguises thereof are dealt with radically and proactively. Generally, the subject of xenophobia is one which almost everyone has an opinion on - therefore this must be a subject close to every person's heart, be this controversial or not.
\end{abstract}

Keywords: Afrophobia, attitude, divide-and-rule, foreigner, hatred, power

\section{Introduction}

With the dawn of democracy in South Africa in 1994, the "Rainbow nation" espoused by retired Archbishop Desmond Tutu was usually perceived as a kind of nirvana or paradise based on the numerous rights and freedoms that were enshrined in its new constitution. These rights, which are enshrined in the Bill of Rights, include freedom of expression, rights to human dignity and equality, freedom of religion, belief and opinion, freedom from slavery, servitude and forced labour, right to life and freedom from torture, inhuman and degrading punishment (Constitution of South Africa, Bill of Rights ss. 7-39). Such elaborate rights and freedoms suggest that the country is a mature democracy in which these and other rights are sacrosanct and greatly respected. Ironically, the situation on the ground in many South African towns, townships, villages and other localities seems to point in another direction. At least since around the year 2000, there have been increasing incidents of hatred, negative attitudes and dislike of foreigners in general from Asian countries but specifically targeting African migrants from the different parts of the continent such as Somalia, Democratic Republic of Congo, Zimbabwe, Nigeria, Ethiopia Mozambique, Malawi, to name a few (ENCA, 2015). Violent attacks on other nationals or some forms of attacks on nationals from these and other African states are a reality we have come to expect time-after-time.

$1 \quad$ Sepa leholo ke la moeti is the Sesotho expression which suggests that whenever anything goes wrong in a home, community or society, blame is attributed towards strangers or foreigners.

2 College of Human Sciences, University of South Africa, P.O. Box 392, Unisa, 0003, South Africa, Email: koenamij@unisa.ac.za

3 Inaugural WIPHOLD-Brigalia Bam Chair in Electoral Democracy in Africa at Unisa, .O. Box 392, Unisa, 0003, South Africa, E-mail: maphukj@unisa.ac.za 
Once again, South Africa confronts the ugly reality of barbaric and cruel acts of attacks on foreign nationals from other African states. Some have labelled such phenomena xenophobic attacks while others conclude that this is nothing more than Afrophobia (Black-on-Black conflict and violence directed at other Africans). Mudimbe in his work entitled: The Invention of Africa (1988) bluntly points to the negative consequences of colonialism on the African soil. One way in which these consequences still haunt Africans is the tendency by some of them to look down on other Africans especially if they are from elsewhere in the continent. In the case of South Africa, the brutal systems of colonialism, racial segregation and apartheid had over centuries inculcated a negative attitude of disdain and hatred of fellow Africans from "beyond the Limpopo". During the apartheid era, many Africans who came to South Africa usually worked in the mines and factories. While this situation might have changed since the country's democratisation, relatively very few South Africans (especially Blacks) ventured beyond the borders of the republic in search of work partly because of the apartheid system's restrictive policies. The end results were that very few South Africans (especially Africans) clearly understood the socio-economic, cultural and political lifestyles of fellow Africans beyond the Limpopo.

We argue that this unsolicited characteristic of being African is never going to disappear completely unless the moral and political disguises are dealt with radically and proactively by all the role-players in South African society. In a sense, radically here means transforming the way we in South Africa do things, including dealing with all aspects of life in settings such as homes, religious and political gatherings and cultural and social meetings, to name but a few. Arguably, a child is born as an amoral and apolitical being who then is socialised into becoming anything we shape this child into be-ing, or what sociologists call socialisation. Child development depends very much on socialisation, which suggests that under ordinary circumstances, every child be-comes what they were taught or developed to be. The attitude they grow up with - that is, their moral outlook and perspective in life is generally what they were taught to be. To use Behavioural Theory, people are conditioned in their early childhood to become who they are at their later adulthood stage. We are yet to meet someone who is not in part or completely a product of their society. Letseka (2013:351) views it thus:
Eventually, I offered my readers African traditional education and the Basotho indigenous education as programmes we might draw onto to address the development of the sort of personhood that is necessary for Ubuntu moral disposition. Justified my choice of Basotho indigenous education on the grounds that is my own native education about which I can write uninhibitedly. I surmised that young people who are initiated into Ubuntu morality have the potential to become citizens that are inclined to treating others with fairness at all times.

In many ways this further suggests that we are all socialised into becoming who we are as well as what we are by our environment. It is also true that we chose at some stage to out-grow certain tendencies we learnt from childhood. But even then, the fundamental reference point still largely remains that of the person's upbringing and essentially shapes their views later in life. As a result of this conviction, we believe that people can and must be educated on how to view the other person. First and foremost, we need to teach ourselves (even more so our young generation(s)) how to treat others as persons before we can notice differences.

Kollapen's primary concern regarding xenophobic actions against other Africans from across the borders (cited in Koenane 2013: 107) is that "not enough was done to understand the 
cause of these attacks". This equally applies to Afrophobia, the blatant hatred and dislike of Africans from other parts of the continent and this, fundamentally, disguises the crux of the matter; which is the basis of any disagreement and conflict. In order to come up with a working solution and reach a common ground the cause of any conflict must be understood. With regard to Afrophobia, probably everyone at the offices believes that they understand the causes of these atrocities. The most striking ones are the now familiar statements such as: "during the apartheid period in South Africa, we stayed in their countries" or "during our time of need in the apartheid era they hosted or welcomed us in their country". There is nothing wrong with these kinds of remarks but the problem is that these statements never made any difference before, they have had no impact in dealing with Afrophobic incidents in the past and might not make any positive contribution in the current state of affairs either. The apparent indifference of the South African society to such statements may be attributed to possible disjuncture between the country's leadership and ordinary citizens who do not understand why they must "share" their country with foreigners, irrespective of wherever they come from. It would seem that some South Africans believe their lives would have been better if foreign nationals were barred from coming to their country; but this belief is clearly false in our view.

\section{Xenophobia or Afrophobia as power relations}

The recent incidents of xenophobia/Afrophobia ${ }^{4}$ and their consequent attacks began in Durban, KwaMashu, and the City Centre and subsequently spread to iSiphingo and a vast number of places in KwaZulu-Natal. The general public (mostly people of goodwill and those whose lives and livelihoods are threatened) is concerned that sooner or later these attacks will spread to the rest of the country, probably targeting new "enemies" such as some other South African ethnic or racial groups. As such, we begin by defining the word xenophobia. For the purpose of this paper, the working definition of xenophobia is taken from Frank Bealey (1999: 344) it is formulated thus:

\section{A fear and hatred of foreigners often reflected in harassment of minority ethnic groups. It may begin as a dislike of people with strange dress and behaviour and develop into specific phobias [...]. Xenophobia may be particularly rife where a community or nation feels threatened.}

Xenophobia or resentment of foreigners is not a unique phenomenon to South Africa, perhaps what could be unique is the manner by means of which this resentment is expressed. Speaking at the Mail E Guardian and University of South Africa Critical Thinking Forum recently (23/04/2015), anti-apartheid stalwart and human rights activist, Advocate George Bizos, made the following remarks on the spate of attacks on foreign nationals in South Africa:

This isn't about fear of foreigners. This is far more malevolent than that: rather, we are dealing here with the hatred of foreigners - as the Greeks would call it, misos gia tous xénous.

In this article, the two concepts xenophobia and Afrophobia are used interchangeably. We however, prefer Afrophobia since it emphasises that it is mostly Africans from other African countries who are always attacked by frustrated locals. We are aware of Pakistanis and other Asian nationals who are doing business in South Africa and who are usually victimised by xenophobic incidents. 
Julia Kristeva in her book entitled Strangers to Ourselves (1991) articulates her own experience of being a foreigner in France. Nyamnjoh (2006: 38) asserts that xenophobia in all its different manifestations affects all societies but emphasises that not all foreigners became targets. Of note are certain elements which according to Bealey constitute a definition of xenophobia. Firstly, he mentions that "xenophobia is fear and hatred of foreigners". Insofar as we are aware both fear and hatred are real emotions, in a sense that people fear something and such a fear has its source. To begin with, he states "fear", we therefore would like to investigate if this is a justified fear or not. In other words, is it rational to fear? We believe that xenophobia/Afrophobia, is a reality which affects people differently and as such people hold different viewpoints about it. Contrary to the belief that xenophobia exists only among Africans, it is not only a problem in South Africa and among Africans only as seen in the current efforts by European countries to keep away Africans fleeing from North Africa through the Mediterranean to southern Europe. Thus, Afrophobia exists at all levels of life and it is expressed in different ways depending on the level at which it operates (Koenane, 2013). We also believe that such fear may or may not be reasonable (again depending on the level from which one finds him or herself). The importance of this investigation is that from a philosophical perspective, fear as an emotion is something neutral, that is, fear does not have any moral dimension on its own. It is only if it is judged as a justifiable or unjustifiable act where it adopts such a moral aspect to it. But again it is not as simple as it looks, since what is justifiable for one person may not necessarily be so for the other person. In other words, people may not necessarily agree with what constitutes justification for acting in a particular manner. Hence, what genuinely constitutes fear in one person may genuinely not necessarily constitute fear in another. However, Afrophobic incidents outline power relations.

Experience teaches us that no matter the progressiveness of a policy or a constitution, a migrant or a foreigner would not have as much comfort in a foreign land as though they were in their own country. In practical sense, power relations characterise the level of comfort a foreigner can enjoy. This again operates within given levels as suggested by Koenane (2013), where he outlines three levels on which Afrophobia is experienced and expressed. Koenane argues that these three levels are:

i. The lower level - which is mostly where the frustrations (reasonable or otherwise) lead to acts of vandalism, violence, attacks and looting. Simply put, at the lower level xenophobia is expressed in barbaric acts. This is the lower moral road.

ii. The second level is characterised by people who do not commit themselves but would simply opine that foreigners must not be attacked or killed as it is the situation in South Africa but that they must go back to their own countries; and indifferent people. This he calls the middle road but he does not commit himself into mentioning whether this is a moral or unethical way. However, in this paper, we would refer to this middle road as a moral disguise.

iii. He further maintains that the third level of xenophobia is a professional level in which violence and criminal acts do not necessarily play a role. Among foreigners in South Africa, there are those who are highly skilled and educated. There is high competition for positions at this level and more often than not these foreigners easily elbow locals aside because of their superior education and experience. In the case of Zimbabweans and to some extent Mozambicans, another factor we often hear is about "hard work". The binary used is that "South Africans are lazy compared to Zimbabweans and Mozambicans who are "hard workers". In other words, foreigners are knowledgeable, 
experienced and preferred to locals. Koenane (2013) suggests that the experience of these foreigners could be used to benefit South Africans who are at the same level of skills and education if and when these foreigners are meant to train and mentor South Africans to acquire skills and experience such as they have. He argues that this in his view is a more moral approach to establishing better relationships between foreigners and locals. For Koenane (2013), this is a high moral road.

The above differentiation reminds us that there are two different kinds of immigrants: voluntary and involuntary immigrants. Immigrants are of heterogeneous groups and their reasons for coming to South Africa vary. Nyamnjoh (2006: 38) rightly affirms that as much as xenophobia is experienced in all societies those who are targeted are chosen carefully by perpetrators, according to him, people are targeted in terms of the hierarchies in the society-. As such, voluntary immigrants are those who willingly go into a host country for different reasons in particular for greener pastures in terms of seeking professional jobs because of their education and skills. Most of those who belong to this group are those affected by xenophobia differently and are generally protected by law since they have work and residence documents which allow them to live in a host country legally. Among these are those who cross borders for economic reasons, usually also termed "economic migrants", even those with little education and little knowledge of this and that (that is, people with no specialised professions in a strict sense of the words - generally referred to as manual labourers). Most of these without specialised professions would also have no legal documents to be in a host country. As such, in most cases the dog-eats-dog situation, which is characterised by violence affects most of these unspecialised general labourers. Competition at this level is rife since there are normally thousands of unskilled job-seekers in a host country such as South Africa. $\mathrm{Be}$ that as it may, there is no moral justification for violating others' human rights whether they are in the country legally or not.

Involuntary immigrants are those who cross borders into other countries unwillingly, these are individuals who are forced by circumstances including political and other forms of persecution in their country of origin. Among these are those who are regarded as political refugees in terms of the United Nations (UN) High Commission for Refugees (UNHCR) Convention Relating to the Status of Refugees (1951) and its 1967 Protocol (UNHCR, 2010). Overall, political refugees are fairly educated but this differs from country to country and in Africa many refugees tend to be women from rural backgrounds who are illiterate (UNHCR, 2009: 48). Essentially, they are politically involved individuals who, because of their opposition to the ruling party in their country of origin, are then persecuted together with their families and as such are pressured into fleeing their own country into exile in another country ${ }^{5}$. Sometimes they are also forced to flee their countries of birth owing to internecine or civil wars, political instability, despotic or authoritarian regimes and myriad violations of their rights as specified under the Universal Declaration of Human Rights. We agree with Pogge (2006: 710) that governments have moral obligation and political responsibility to give such people a refugee status and South Africa is within its rights in terms of international law to accept refugees into its territory. Amnesty International (2002)

However, there must be a an element of persecution and fear of such by anyone so defined. The UNHCR Convention Relating to the Status of Refugees (1951) defines a "refugee" as "someone who is unable or unwilling to return to their country of origin owing to a well-founded fear of being persecuted for reasons of race, religion, nationality, members of a particular social group, or political opinion" (UNHCR, 2010: 3). 
confirms that a number of governments imprison, persecute and torture their political opponents. Since fleeing is one of the main reasons people live in exile, it bothers us that countries continue with political disguises by evading serious issues which ought to be addressed. Issues which make people flee their countries are generally political issues; as such political remedies ought to be found in addressing this particular problem.

In Africa, the African Union was established originally as the Organisation for African Unity (OAU) with a hope of addressing African problems head-on and to ensure that Africans throughout the continent are liberated from the yokes of slavery, colonialism and white minority governments that used to plague many parts of the continent. To what extent this is taking place, given the tendency of African governments to hide such matters within the cloaks of diplomacy and "national interest", is difficult to discern but it looks to us as though there is an avoidance strategy in dealing with real political problems which negatively impact on the continent. Yet, seriously addressing issues which pressurise people to flee their own countries would undoubtedly ensure that people are safe and protected and thus obviate the need to flee. This would further ensure political freedom and freedom of speech and other fundamental human rights that are often trampled upon easily by African governments. Furthermore, this would help to safeguard constitutional change of government through the holding of credible democratic elections that comply with international election management best practices. Incidentally, the African Charter on Democracy, Elections and Governance, which was adopted by the African Union in 2007, clearly stipulates the relevant steps that African governments must take to enhance democratic rule in their own countries (ACDEG, 2007). In the end, the enforcement of this Charter is left to the same governments that usually drag their feet in implementing such agreements.

As the UN Convention for Refugees attests (UNHCR, 2010), it is not only political views that make people targets in their own countries; and, religion also plays a role in people fleeing their countries. In some cases, some religious groups and sects are usually persecuted for not participating in the political and other processes of their countries. Some religions have imposed extremely harsh penalties against their own members to such an extent that people would denounce their religion and flee for their lives. Again this is an issue which should be checked against compliance with national laws, continental instruments and international law since all people first and foremost belong to a state.

Evidence suggests that South Africa experiences several impediments to democratic consolidation, suggesting that the country is deply divided along "racial, ethnic and linguistic lines" (Gibson \& Gouws, 2000: 278). Similarly, it experienced political tolerance shortly after the demise of apartheid. This may not be dissimilar to the presence of political intolerance and religious oppressive laws in some African states which, inevitably, will require a political solution. Such a solution, however, does not imply that African governments must sweep blatant violations of human and democratic rights under the carpets and that, with collusion from western governments; they should pay lip service to the obligations of the Universal Declaration of Human Rights including African human rights obligations. Undoubtedly, the situation of people crossing borders legally or illegally to get jobs or make money from other countries would always be an urgent political problem which needs to be urgently addressed especially if it looks to insiders as though foreigners are preferred over them. ${ }^{6}$ Thus, there is need for robust political debate in South Africa which may lead to

Anecdotal evidence and public talk in taxis, buses, trains and other public forums suggests that some employers do not always hide their preference for foreign nationals in certain industries especially 
finding a sustainable political remedy to this situation. Unfortunately, extreme poverty is one of the characteristics of the new South Africa, resources are not enough for everyone and as such competition for these limited resources causes frustration on locals. Unemployment on all levels is a serious matter to an extent that competing as an underdog would always threaten one who is at the disadvantage.

\section{The mind set and xenophobia}

In his work, I Write What I Like, Steve Biko (1978) argues that the most powerful weapon at the hands of the oppressor is the mind of the oppressed. This is further supported by Mzwakhe Mbuli in one of his songs where it states: ukulimala kwenqondo ukulimala komuntu. Literally, this means that once the mind of the human being is damaged the whole person is damaged beyond repair. In simple terms, this article argues that the problems about certain systemic structural rules of engagement are deep-seated in the minds of individuals. Certainly, xenophobia manifests itself differently - this depending on the level at which it operates. However, in all its manifestations xenophobia has everything to do with power relations. Power relations, which are some of the main causes of Afrophobia, reasonable or unreasonable, were entrenched initially through a well-orchestrated project of the apartheid regime namely the divide-and-rule strategy mostly based on race and ethnicity. This strategy worked and some South African leaders and elsewhere in the continent may have found it appealing as a means to prolong their stay in power.

During the apartheid era, the so-called Black-on-Black violence, which was essentially orchestrated by the regime, was an effective tool which the apartheid government used to its advantage to undermine genuine and organised resistance to its illegitimate rule and draconian policies. In order for this violence to take effect, the apartheid regime had to ensure that the divide-and-rule strategy was in place by carefully co-opting collaborators and elements from the former Bantustans who were forced to accept the legitimacy of apartheid in return for concessions from the then White-dominated government. How the strategy worked was simply to turn Africans against each other. For instance, one group was made to believe that they were "better" than the others and thus "superior", while at the same time the same group which was made to believe they were "better" was reported to other Black groups as a "sell-out" group. As a matter of fact envy and jealousy were the order of the day, these groups began to hate one another and the hatred aggravated to a deeper level. Individuals from these different groups began to see others as enemies, which must be defeated or perpetually undermined; and, in a true Sartrean sense, Afrophobia is an act of viewing the other Africans as "hell". This is typified by the negative naming of the other which is expressed differently using derogatory terms such as: makwerekwere, izifikanemithwalo, matswantle, etc. (Koenane 2013: 106).

In terms of the apartheid psyche or ingrained attitudes, a concerted attempt was made by consistent state propaganda and disinformation campaigns to discredit African "beyond the Limpopo" by painting a picture of "backwardness, violence and death". This was often done through biased films, radio broadcasts and newspaper articles. Thus, many South Africans grew up either hating people from such countries or at least being suspicious of their presence

hotels and catering, construction and agriculture. Observation by the authors on the nationality of individuals employed in some major retail, hotels and catering outlets in cities such as Johannesburg, Pretoria and Cape Town suggests that (unstated or unofficial) preference by these outlets is disproportionately leaning towards foreign nationals.

Td, 10(4), December 2015, Special edition, pp. 83-98. 
within their midst. The anti-apartheid war against the state, while it ultimately exposed the bankruptcy of the apartheid laws and policies nevertheless did not help much in demystifying many stereotypes created by the apartheid regime.

Most often than not, cultures embody attitudes towards others in particular those who do not belong to "our own group(s)", which is a manifestation of the "us and them" syndrome. Xenophobic attitudes have everything to do with the mind-set, negative in this case. For instance, among the Basotho culture, there is a proverb which largely expresses an attitude towards foreigners or strangers as follows: "Sepa leholo ke la moeti [...]" . Current and past xenophobic attacks and attitudes in South Africa are characterised by allegations and accusations of foreigners engaging in criminal acts. Making foreigners scapegoats for things which go wrong is a hypothesis which most authors have explored (Wilson, 2015). These include taking out frustrations on foreigners for poor service delivery (Fauvelle-Aymar \& Segathi cited in Landau 2011: 59). In other words, foreigners are blamed for crime and political failures which they too have no control over. Evidence of this is elucidated by Landau (2011: 9-10) wherein he quotes the late Joe Modise's (the then Minister of Defence) utterance where he remarked thus:

As for crime, the army is helping the police to get rid of crime and violence in the county. However, what can we do? We have one million illegal immigrants in our country who commit crimes and who are mistaken by some people for South African citizens. This is the real problem (Landau, 2011: 9).

This statement can be read together with that of Billy Masethla, who proposed that strong action must be taken against criminals. Masethla asseted as follows:

Approximately 90 per cent of foreign person who are in RSA with fraudulent documents, ie, either citizenship or migration documents, are involved, in other crimes as well ... it is quicker to charge to these criminals for their false documentation and then to deport them than to purse the long route in respect of the other crimes that are committed (Landau, 2011: 10).

Accodingly, both this statemen are convinced that foreigners are a problem since most of them are criminal elements that should be taken care of. Foreginers are equated with crime thus Sepa le holo ke la moeti. Evidently foreginers are blaimed for everything that goes wrong It is for this reason the authors argue that all efforts to address xenophobic attitude and violence is a political disguise.

Kristeva (1991) differentiates between citizenship and foreignness. In her work: Strangers to ourselves, Kristeva (1991: 95) asks the question: "by what right are you a foreigner?" She then moves on to what she terms jus soli, jus sanguinis. She is basically concerned with that which constitutes a foreigner or put differently, she wonders how best we could define a foreigner. She explores all sorts of avenues, could a foreigner be someone who does not belong to a particular group? Or is the foreigner someone born in another country (Kristeva, 1991: 95). She maintains that in terms of a foreigner, two legal systems were created. Firstly the jus soli, which is Latin for the right of the territory; she refers to the right by which nationality or citizenship can be recognised. Secondly, the jus sanguinis this refers to the rule through which birth in a state is sufficient to confer nationality, irrespective of the nationality of one's 
parents. Both definitions suggest some new definition of a nation state in which the foreigner has no place. Analysing the situation from her European context, Kristeva (1991) is curious at how foreignness attracts such negativity and fear. She further articulates that the possibility of threat or benefit from the other (foreigner) dictates what rights are offered to him or her.

On the lower level in respect of education, self-reliance and skills, the assumption is that the other (foreign nationals) must not have rightsand must be excluded from public service. In terms of the power relations argument propounded in this article, this is a typical example wherein the powerful (police or the state in this case) clearly prey on the powerless ("undocumented" or illegal migrants). Such practices have deep roots in the modus operandi of the South African Police during apartheid whereby virtually all Africans or black people were generally presumed guilty until proven otherwise. During such encounters, police brutality at its worst including the indiscriminate unleashing of police dogs on Africans was the norm in many black townships. We find this disturbing and, therefore, we believe that something should be done to legitimise the stay of Africans from other parts of the continent in the country and thus extend legal protection to them as well.

\section{Empty rhetoric and political disguises}

Xenophobic attacks and incidents of violence against African others occur year-in and yearout. We hear the same rhetoric every time these incidents occur; this rhetoric has up-untilnow had no impact and has not made any difference. This leads us to ask this question: is our government serious about curbing xenophobia among South Africans? The new rhetoric reads as follows: \#SayNoToXenophobia and \#Simunye ${ }^{8}$ - Africa Unite. However, as the word suggests, rhetoric implies hollow promises or verbal declarations that are not backed by concrete action. Some South Africans anecdotally acknowledge this rhetoric but ascribe it to the fact that "foreigners cannot win votes", alluding to the fact that politicians from the governing African National Congress (ANC) and the opposition are not always that enthusiastic about issues pertaining to Afrophobia and xenophobia since foreign nationals are legally barred from voting. If this view is correct, it might serve as partial explanation to the apparent official lethargy or reluctance to take meaningful action in dealing with this phenomenon that continually keeps embarrassing the country (ENCA, 2015; Wilson, 2015).

With a few slogans, radio, television and print media campaigns that have been undertaken in 2008 and in 2015 when the attacks against other Africans occurred, we ask the question: Is this the best we can come up with? To answer these two questions, it appears that not enough is done to stop these xenophobic attacks. The attacks are mainly directed to the vulnerable sections of foreigners living in South Africa, that is, those in the lower level of the economy, those without specialised skills or education, those who do not have legal documentation to be in the country.

In every country, issues of development are of primary concern for government, particularly in developing countries. Therefore, in order for development to effectively take place, a country should have a reliable estimation or accurate population statistics of people living in the country, which includes foreigners living in a given country. As observers have argued, this is part of the usual requirements of good governance that governments are expected to comply with (Davids, Theron \& Maphunye, 2005: 64). South Africa is no exception in this regard. Arguably, therefore, those entering the country illegally render development efforts 
ineffective as this strikes at the heart of development and economic planning aimed at providing services for all citizens. This problem thus needs to be addressed. In cases where foreign nationals are properly documented, we believe xenophobic attacks would be minimised since these foreign nationals are protected by law. However, this means that all the other variables will also have been taken care of such as corruption among state officials such as police, other security agencies and Home Affairs employees. This applies equally to illiteracy, high unemployment and poverty. Kristeva (1991: 96) writes:

If political regulations or legislation generally speaking define the manner in which we
posit, modify, and eventually improve the status of foreigners, they also make up a
vicious circle for it is precisely with respect to laws that foreigners exist. Indeed without
a social group structured about a power base and provided with legislation, that
externality represented by the foreigner and most often experienced as unfavourable or
at least problematical would simply not exist.

We agree with Kristeva (1991) that taking care of what exposes foreigners to exploitation of any sort and legalising their stay in the country is for us the first step in the right direction. This would further provide foreigners with political rights thus making them responsible members of society with rights and obligations like all other nationals. In this way, South Africa would in a true sense of the word belong to all who live in it. What Kristeva (1991) and Wilson (2002) later on challenge us to do is to work towards self-knowledge or selfrealisation of who we are. Wilson in the book with a similar title as that of Kristeva: Strangers to Ourselves argues that in order to know ourselves better, we need to find a way of discovering our unconscious selves. He further articulates that for one to know oneself, and how one feels all one needs to do is to take into consideration what one actually does. In other words, our actions define who we are or what we are. Put differently, xenophobic acts define South African culture in terms of our relationship with Africans from within the continent. Xenophobic incidents stigmatise South Africans in general. They define South Africans as intolerant, violent, heartless and generally brutal to those speaking different language(s) especially if these come from another African country. This, to some extent, exposes the hypocrisy and essence of the so-called 'xenophobia' as being actually "Afrophobia". For instance, we have hardly witnessed any incident wherein refugees from the former Eastern Bloc countries such as Czechoslovakia, Bosnia-Herzegovina, Slovenia, and other former Yugoslavian territories were exposed to acts of "xenophobia". Yet some from such countries have over the years settled in South Africa and were readily accepted as "Whites". They may not have settled in some African township or village but in this case it would appear that the Black-White binaries of the South African society seems to have ascribed a "superior" (White) status to them unlike the African migrants who bore the brunt of blatant discrimination.

Treating others differently with a view to discriminate unfairly against them is a deep-seated problem among Africans in particular (ENCA, 2015). For example, the Zulu people in deep KwaZulu-Natal would refer to any Sesotho speaking groups as izilwanyana (little animals); check this out, they are not even animals but little animals because they consider them to be inferior, a negative ethnic mind-set which Steve Biko cautioned against when he coined the slogan: "Black man, you're on your own". This kind of attitude is also reflected in Hugh 
Masekela's hit song, Chileshe, in which he cautions against looking down on others, calling them derogatory names and treating them in any inhumane manner. In the song the Zulu people represented by Ngobese refer to others as izilwanyane (little animals). Interesting enough, in the song, Dlamini (representing the Swazi people refers to others as abantu bezizwe (foreigners) or those who belong to other cultures. Again, referring to other Africans as foreigners is clearly not acceptable to Masekela. Technically, it does not make sense to call Africans foreigners anywhere in Africa - this is their mother continent divided by artificial borders created or invented by colonisers at the 1884 Berlin Conference. Frankly, attitude and prejudice are learnt or acquired, but most importantly they are internalised. It is for this reason that we argue that people could be taught early on in their lives to adopt a positive attitude towards others. Furthermore, the country does not deserve the rhetoric and apparent indifference by politicians from all political formations as this has clearly proved ineffective and suggests that South Africans merely criticise Afrophobic acts whilst in principle not doing much that is sustainable in practice. Our approach also urges all individuals and civil society organisations to assist the state to address the manifestations of negative attitudes and prejudice among their compatriots, (ENCA, 2015; Wilson, 2015).

\section{Way forward}

Avoidance strategy is in our view fuelling incidents of xenophobia and Afrophobia in South Africa. This avoidance strategy is what we earlier referred to as political disguise. Political disguise is understood as a political strategy to refuse or avoid addressing pressing issues such as immigration policies in the name of maintaining good relations with other countries. We believe that every child is born amoral that is without a sense of morality; as such, morality in human beings is something people learn as they grow up. We therefore believe that introducing moral education from early age schooling would make a difference in terms of people's attitudes- towards others. In this respect, all approaches to moral education would be of great help especially Aristotle's approach of character ethics. The reason we advocate for Aristotle's virtue ethics is simply that it emphasises the character of the moral agent. Since it emphasises the character of the moral agent, it thus presupposes character formation. Better citizenship and sensitivity towards the other could be established earlier in the moral formation of our children.

Kristeva (1991: 97) moves on to note that as much as certain groups whose philosophy is based on Stoicism and the Judeo-Christian religion have offered some equal status and equal rights to foreigners these are only realistic in a spiritual city since another set of group is created to exclude foreigners from benefiting from the country's resources. Like Kristeva (1991), we believe that this is where the political power or the state in its broader sense should play its role. How the political order plays its role is for us a serious moral matter. Certainly, politics has everything to do with distribution or allocation of limited resources in a given country. Some believe that charity begins at home; by this, the respondents meant that these scarce resources must benefit South Africans in the legal sense of jus soli; jus sanguinis. This theory obviously excludes foreigners, therefore where these foreigners benefit from the country's resources, locals are inevitably frustrated, jealous and strategize and react by victimising the foreigners who seem to be benefitting disproportionately from government interventions such as RDP (Reconstruction and Development Programme) houses and small business initiatives especially in the Black townships and villages (Wilson, 2015). 
The question of resources raises another serious question for Julia Kristeva (1991). She asks: do we have rights as men and women or as citizens? She argues that insofar as resources or rights are allocated in terms of a citizen and a non-citizen, it is equal to recognising one as fully human while the other, a non-citizen, is regarded not as a human being (Kristeva, 1991: 98). Kristeva (1991) additional emphasises that the idea of exclusion is closely connected with the idea of nation-state, as such she recommends two solutions to this problem. First, she recommends the global united states of all former nation-states where the rights of all human beings are integrated. Second, she recommends small political sets designed by humanistic cosmopolitanism with a statute introduced to protect the rights of foreigners (Kristeva, 1991: 98). Certainly, Kristeva's (1991) view is not new to Africa. It seemingly reminds us of the ideas of the pioneers of the Organisation of African Unity (OAU) in 1963 when the likes of Kwame Nkrumah of Ghana were strongly advocating for a "United States of Africa" and a continent free from colonialism and White minority rule. Of course, probably owing to the reformism from which the OAU subsequently suffered, the question of the borders fell out of its agenda (AU, 2002). In 2002 when the Organisation of African Unity became the African Union, such ideas again surfaced but Africans are still awaiting to see the full commitment and political will of all their governments to such ideas. Thus, Kristeva's (1991) argument is not far-fetched. However, the greatest challenge will be on the nature and development of such a "United States of Africa" including the actual types of "small political sets designed by humanistic cosmopolitanism".

In Koenane (2014: 2) discusses what she refers to as self-defeating behaviour. We therefore believe James' theory of self-defeating behaviour applies perfectly well in acts of xenophobia and Afrophobia (regarded by many as Xenophobia). Accordingly, reacting also has some selfdefeating consequences as well. Consequently, understanding Kristeva's analysis of "Strangers to ourselves", she maintains that we are strangers to ourselves and that which we fear in ourselves needs to be dealt with and accepted in others for us to be able to understand and accept the stranger in others. The growing frustration on other things such as joblessness, scarce resources and political failure to provide services are not reasons enough to take out the frustration on innocent people from other African countries or elsewhere in the world. A xenophobic and Afrophobic environment has been allowed to exist for a long time now; and, this environment breeds all kinds of violations and criminal activities ranging from rape, looting, violence, inhumane treatment of others and many other injustices against foreigners who are perceived by locals as a serious threat. Yet, the capacity of the state to deal with all these acts of criminology and lawlessness also needs to be brought under scrutiny here. Why, for instance, do we constantly see incidents of locals appearing on national television and print media looting "foreigners' shops" and yet seeing police standing idly by when such acts are perpetrated? (ENCA, 2015; Wilson, 2015) Why have we not seen any prosecutions of the perpetrators of the 2008 violence against foreign nationals, many of whom also appeared daringly on national television? (ENCA, 2015). The answer can only point to the fact that South Africa's state is increasingly becoming "soft" or weak and therefore incapable of addressing such crises. This, for us, also accounts for the current crisis and dilemma facing the country in terms of xenophobia and Afrophobia.

As much as other scholars express their disillusion regarding Ubuntu as a concept on which a South African identity could be established, we argue that given the idea that Ubuntu emphasises certain character traits that only could promote friendliness, caring and values that could foster good behaviour, it is our duty to promote the idea of Ubuntu and teach 
young people from early on in their lives to cherish Ubuntu ideals. In supporting the ideals of Ubuntu Landau (2011: 229) writes:
While the emphasis on a just and caring society reflects an implicit criticism of capitalism's inhumanity, [...], Ubuntu's action plan - helps shroud a demon to create national cohesion means to overcome difference in a country which, if nothing else, is characterised by difference.

Therefore we believe Ubuntu values cannot be discarded that easily as most scholars argue that these are needed to establish a cohesive South African cultural identity. We believe that from a moral perspective, South Africa needs strong leadership that would pave the way in dealing with xenophobia systematically and sustainably. We further need clear policies in terms of dealing with xenophobic incidents in their manifestations. Unless tough action is taken against xenophobia in all its manifestations, these incidents will reoccur and define South Africa for ages to come. The negative attitude and lack of trusting the other has characterised South Africa for a long time. MacIntyre (2007) argues that behaviour cannot be characterised independently of intention. If MacIntyre's assertion is correct, then xenophobic/Afrophobic violence and attitude must have an intention - it is this intention which must be uncovered. We likewise believe that incidents of violating the other such as Afrophobia attacks, violence, looting and killings would stop if in our school curricula, subjects and modules that are directed at shaping the lives of South African citizens are introduced from early on and are carried through. Akinpelu (1981) rightly argues that any system of education would not necessarily change people but education gives individuals an opportunity to make informed choices and further enables them to internalise what they have been taught and personalise it.

Political will is another critical part of the equation because once the political will and determination on the part of leaders is strong enough, Afrophobia in all its manifestations its related incidents would be addressed effectively. Such political will is quite critical given the fact that whenever the leadership does not seem to prioritise an issue, the general public might erroneously assume that such issue is unimportant. ${ }^{10}$

Finally, we believe that borders we invented to with an intention to divide Africa, and if Mudimbe's thesis of The Invention of Africa is correct, then the new Africa could be reinvented by eliminating borders and allowing Africans to move freely in the continent without the hindrance of visas and other such hurdles to freedom of movement. We similarly believe that Africans must be allowed to have unconditional dual or multi-citizenship in Africa. Furthermore we suggest that addressing all the real issues that affect Africans with honesty will contribute positively towards solving the problem such as Afrophobia - this is indeed working towards what Landau calls exorcising the demons within. Exorcising the demons from within would be the most moral thing to do than adopting the political and moral disguise strategies which in our view are not sustainable solutions to the current intractable problems facing African migrants in South Africa and elsewhere in the continent.

10 In April 2015, Zulu King Goodwill Zwelithini was quoted as saying: "We ask that immigrants must take their bags and go where they come from" (ENCA, 2015). Following these comments, official response from the highest echolons of government was muffled and no forceful message was sent out to condemn such anti-foreigner sentiments. Instead, the official line was that the King was "misquoted"; hence there was need to "investigate" what the monarch really said. 


\section{Conclusion}

Afrophobia remains a threat to Africa's long-term stability. However, serious efforts, which will address the concerns of locals in South Africa and other countries, have not yet taken place. This is informed by the fact that most countries react instead of addressing the issue proactively. Countries affected by border problems need to adopt different strategies than just empty political disguises and rhetoric.

It was pointed out that in most situations, the Basotho proverb "Sepa lebolo ke la moeti, [...]" is just a strategy to escape blame and apportion it on someone else especially a stranger; which is a way of avoiding confronting a problem. We believe this Basotho expression does not always reflect or express truth. Foreign nationals cannot be a scapegoat for all social ills that South Africa is confronted with. Like other crises situations, we all need to learn lessons regarding things that should not happen in our history. This prevailing hostility between Africans leaves families broken and destroy trust among Africans, xenophobic incidents in South Africa have proven that no one is the winner; we all become losers at the end.

Fighting Afrophobia is not an individual responsibility; and, it is a responsibility of the entire society. It is for this reason that the leadership, traditional, political and religious and from other civil society sectors, must lead the way. Failing to address this from the leadership perspectives may mean that we have weak leadership morally and politically. We argued that with the introduction of certain subjects and modules in our education system, citizens' lives may be shaped and that this is important towards shaping the attitudes of society towards others. We further argued that in order for South Africa to achieve its objectives in terms of fighting xenophobia, we need true political will and strong determination on the part of our leaders including pro-active initiatives by political parties and all role-players.

\section{Recommendations}

We suggest that serious political remedies ought to be found in order to address this problem which, as we have established, does not affect South Africa alone. We therefore suggest that it is time a sustainable political solution is found to the problem of borders, which was apparently shelved when the OAU decided to tackle the challenges of colonialism in Africa. We suggested that borders in Africa must be abolished for Africans to be allowed free movement in the continent. However, we insist that this must be accompanied by African governments' compliance with all the relevant continental and international instruments such as the Universal Declaration of Human Rights and the African Charter on Democracy, Elections and Governance, among others. Such instruments, we maintain, essentially seek to promote free, just, and democratic rule which will subsequently deter citizens from fleeing from one polity to another. Finally, an effective strategy that would eradicate xenophobic attitudes and behaviours at all levels is recommended but may not be an immediate feasibility given the factors raised here.

\section{References}

ACDEG, 2007. African Charter on Democracy, Elections and Governance, African Union Commission. http://www.africa-union.org/rot/au/Documents/Treaties/treaties.htm [Accessed: 11 May 2015].

Akinpelu, J.A. 1981. An Introduction to Philosophy of Education. London and Basingstoke: MacMillan Press Ltd. 
Amnesty International, 2002. Report 2000. Baltimore: Lucas Publishers.

African Union (AU), 2002. Transition from the $O A U$ to the African Union. http://www.au2002.gov.za/docs/background/oau_to_au.htm [Accessed: 30 May 2015].

Bealey, F. 1999. The Blackwell Dictionary of Political Science: A user's Guide to its Terms. Malden, MA: Blackwell Publishers.

Biko, S.B. 1978. I Write What I Like: 1946-1977. London: Heinemann Publishers.

Davids, I. \& Maphunye, K.J. 2005. The public sector: Promoting development and good governance. In Davids, I., Theron, F. \& Maphunye, K.J. (eds.), Participatory Development in South Africa: A Development Management Perspective. Pretoria: Van Schaik.

ENCA, 2015. Checkpoint. eNews Channel, 31 May 2015.

Fauvelle-Aymar, C. \& Segatti, A. 2011. People, space and politics: an exploration of factors explaining the 2008 anti-foreigner violence in South Africa. In Landau, L.B. Exorcising the Demons Within: Xenophobia, Violence and Statecraft in South Africa. Johannesburg: Wits University Press.

Gibson, J.L. \& Gouws, A. 2000. Social identities and political intolerance within the South African mass public. American Journal of Political Science, 44(2): 272-286.

Koenane, M.L.J. 2013. Xenophobic attacks in South Africa - an ethical response: Have we lost the underlying spirit of Ubuntu? International Journal of Science, Commerce and Humanities, 1(6): 106-111.

Koenane, M.L.J. 2014. Towards an ethical contextualisation of Freud's theory of personality. Phronimon, 15(1): 1-15.

Kristeva, J. 1991. Strangers to Ourselves. LS Roudiez, New York: Columbia University Press.

Landau, L.B. (ed.). 2011. Postscript: positive values and the politics of outsiders. In Landau, L.B. (ed.), Exorcising the Demons Within: Xenophobia, Violence and Statecraft in South Africa. Johannesburg: Wits University Press.

Letseka, M. 2013. Anchoring Ubuntu morality. Mediterranean Journal of Social Sciences. 4(3): 351-359.

MacIntyre, A. 2007. After Virtue, $3^{\text {rd }}$ edn. London: Gerald Duckworth \& Co. Ltd.

Mail \& Guardian and University of South Africa Critical Thinking Forum, 2015. "Bizos: 'I know, too, what it means to be a foreigner'”. http://mg.co.za/article/2015-04-23-bizosi-know-too-what-it-means-to-be-a-foreigner [Accessed: 30 May 2015].

Mudimbe, V.Y. 1988. The Invention of Africa: Gnosis, Philosophy, and the Order of Knowledge. Blooming and Indianapolis: Indiana University Press.

Nyamnjoh, F.B. 2006. Insiders and Outsiders: Citizenship and Xenophobia in Contemporary Southern Africa. London and New York: CODESARIA Books in Association with Zed Books.

Pogge, T. 2006. Migration and poverty. In Gooding, R.R. \& Pettit, P. Contemporary Political Philosophy: An Anthology, $2^{\text {nd }}$ edn. Malden, MA: Black Publishing. 
UNHCR, 2009. UNHCR Statistical Yearbook. www.unhcr.org/ [Accessed: 08 October 2015].

United Nations High Commission for Refugees (UNHCR), 2010. Convention and Protocil Relating to the Status of Refugees. Geneva: UNHCR.

Wilson, T.D. 2002. Strangers to Ourselves: Discovering the Adaptive Unconsciousness. Boston, MA: Harvard University Press.

Wilson, K. 2015. Analysis: Are Foreigners Stealing Jobs in South Africa? https://www.africacheck.org/...analysis_are_foreigners_stealing_jobs_in_south_africa / [Accessed: 08 October 2015]. 